DOI https://doi.org/10.30525/978-9934-26-046-9-23

\title{
ПІДВИЩЕННЯ ЕНЕРГОЕФЕКТИВНОСТІ КОВШОВИХ РОБОЧИХ ОРГАНІВ ЗЕМЛЕРИЙНИХ МАШИН ЗАСТОСУВАННЯМ ГНУЧКИХ ГУМОТКАНИННИХ ЕЛЕМЕНТІВ
}

\author{
Карпушин С. O. \\ кандидат технічних наук,
} дочент кафедри будівельних, дорожніх мачин і будівництва Центральноукраїнський національний технічний університет м. Кропивницький, Украӥна

Пантелеснко В. I.

кандидат технічних наук, дочент кафедри будівельних та дорожніх машин Придніпровська державна академія будівниџтва та архітектури м. Дніпро, Україна

\section{Червоноштан А. Л. інженер}

Придніпровська державна академія будівництва та архітектури м. Дніпро, Україна

Землерийні машини з ковшовими робочими органами (PO) є найбільш розповсюдженими і часто використовуваними. Досвід використання машин даного типу - майже століття, вказує на існуючі суттєві недоліки, що притаманні класичній конструкції РО. Серед них налипання та намерзання грунту [1] на РО, зокрема зниження корисної ємності ковша. Попередніми дослідженнями встановлено, що найбільша інтенсивність налипання грунту на металевий РО відповідає вологості грунту від 20 до 33\% [2].

Проблема може бути вирішена застосуванням гнучких елементів (ГЕ) у вигляді металевих ланцюгів. В РО землерийних машин ковшового типу застосування металевих ланцюгів можна спостерігати в якості днищ багатоківшевих роторних екскаваторів ЕРШРД, ЕРГ, ЕРП, ЕР [3]. Перевагою даного РО перед традиційними ковшами $\epsilon$ реалізація ефекту інерційного розвантаження - самоочищення (вільного падіння гнучкого днища з грунтом при розвантаженні). 
Однак, гнучкий, металевий ланцюговий або кольчужний елемент РО має і суттєві недоліки, які стримують його впровадження в конструкції екскаваторів, фронтальних навантажувачів, скреперів. Це неефективність роботи з сухими сипучими матеріалами поєднана 3 невідповідністю нормам запиленості робочого майданчика, висока питома вага, недостатня довговічність, кінематичні обмеження застосування (необхідність гравітаційного та обмеженість відцентрового розвантаження РО).

В результаті проведеного аналізу переваг та недоліків ГЕ ковшового РО можна зробити наступні попередні висновки:

- в конструкціях універсальних, найбільш розповсюджених землерийних машин ГЕ РО застосування не знайшли;

- РО з ГЕ недостатньо досліджені та мають резерви щодо поліпшення складових робочого циклу землерийних і меліоративних машин ковшового типу;

- в якості ГЕ РО варто розглянути доцільність застосування суцільного міцного та високодеформативного матеріалу (листова гума, листова гумо-тканинна стрічка (модуль пружності Е-250МПа), сучасні вологостійких, антифрикційних і водночас міцних полімерних, синтетичних та ін. матеріалів).

Застосування суцільного гумо-тканинного елементу (ГТЕ) в конструкції РО землерийної машини може мати комплексну перевагу у порівнянні з традиційним або гнучким ланцюговим РО по ряду конструктивних показників. Цими показниками $є$ :

- суцільність ГТЕ, що дає змогу розробляти сухі грунти, матеріали;

- антифрикційні властивості ГТЕ в наслідок конструктивної можливості його анізотропного деформування та можливості місцевої дискретизації;

- антикорозійні властивості ГТЕ;

- менша в порівнянні з ланцюговими елементами вага ГТЕ;

- можливість реалізації ефекту інерційного розвантаження - самоочищення (вільного падіння гнучкого днища з грунтом при розвантаженні і самоочищення порожнини ковша внаслідок деформації додаткового гнучкого днища;

- адаптація до форми днища ковша, можливість листового ГТЕ змотуватися в рулон, (намотуватися на барабан рис.1);

- самоочищення поверхні ГТЕ під час висихання та деформації, зокрема при змотуванні на барабан; 
- можливість ефективного застосування для скреперів, фронтальних навантажувачів, універсальних одноківшевих і багатоківшевих роторних екскаваторів.

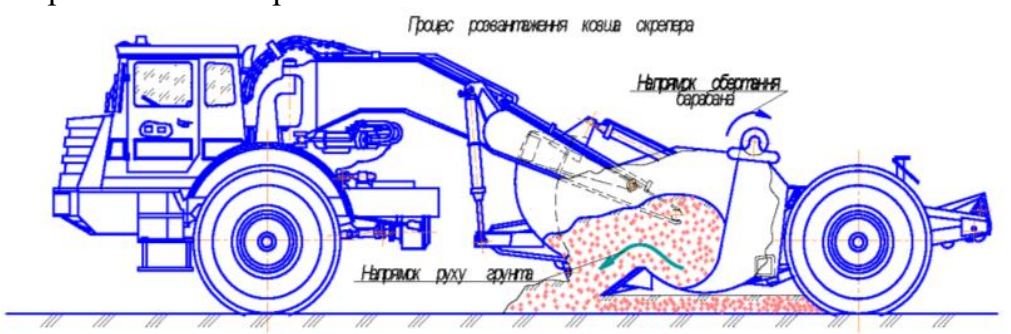

Рисунок 1. Скрепер з криволінійним каркасним днищем і ГТЕ [4]

Для одноківшевого екскаватора з робочим обладнанням «зворотня лопата» пропонується застосування ГЕ у вигляді листа гумотканинної (конвеєрної) стрічки з модулем пружності $\mathrm{E}=250 \mathrm{MПа}$ (рис.2).

Робоче обладнання одноківшевого екскаватора [5] включає рукоять 13 шарнірно-приєднаним ковшем 2, гідроциліндр керування 3 i вузол утримання грунту в ковші, що виконаний у виді ГТЕ 4 з шириною, рівній ширині ковша 2 та закріплений верхньою частиною посередництвом двох металевих пластин 5 і різьбових з'єднань 6 до рукояті 1, причому верхня половина ГТЕ 4 суцільна, а нижня має вертикальні прорізи у вигляді стрічок.
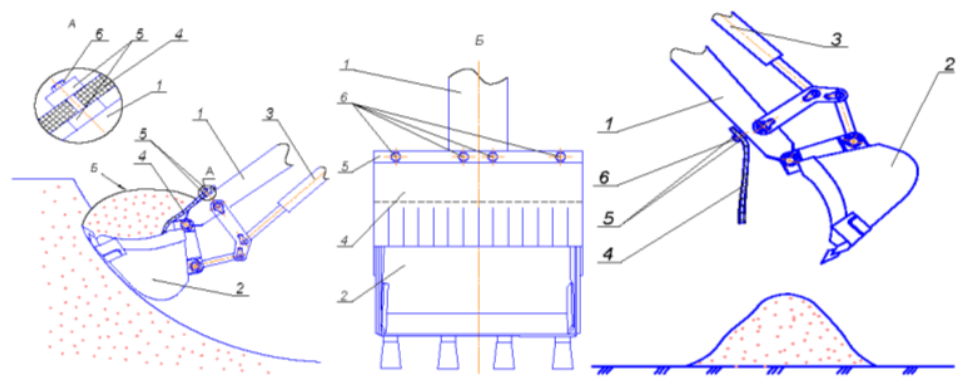

Рисунок 2. РО одноківшевого гідравлічного екскаватора з ГТЕ [5] 
Робоче обладнання одноківшового екскаватора працює наступним чином.

На початку копання шток гідроциліндра 3 керування втягнутий, ГТЕ 4 закріплений на рукояті 1 за допомогою двох металевих пластин 5 і різьбових з'єднань 6 та вільно звисає у внутрішню порожнину ковша 2.

При копанні грунту (див. рис.2), зрізана ріжучою крайкою ковша 2 грунтова стружка потрапляючи в ківш, притискає ГТЕ 4 до задньої внутрішньої стінки ковша 2, збільшуючи іії поверхню. Кінцеве положення ковша 2 (шток гідроциліндра 3 повністю висунутий) супроводжується ефектами затискання і фіксування набраного в ківш грунту, ГТЕ 4. При цьому просипання грунту на шарніри кріплення ковша 2 i елементів його приводу до рукояті 1 не відбувається. Переміщення ковша 3 грунтом здійснюється при менших втратах грунту на просипання. Розвантаження ковша (див. рис.2) супроводжується ефектом «струшування» налиплого на лист 4 грунту, при цьому інерційна складова цього ефекту передається і на інші елементи робочого обладнання, тим самим сприяючи очищенню РО.

Виконання ГТЕ 4 з розрізами в його нижній частині забезпечує його еластичність та адаптування до внутрішньої поверхні ковша 2 при завантаженні грунтом і володіс само очищувальними якостями при розвантаженні.

Таким чином, застосування в конструкції РО одноківшового екскаватора або фронтального навантажувача ГТЕ, верхня частина якого суцільна, а нижня з прорізями у вигляді стрічок, підвищує продуктивність ковшового екскаваторного обладнання за рахунок набору більшої кількості грунту, його утримання в процесі переміщення ковша $\mathrm{i}$ меншого просипання. Ці ефекти максимальні при роботі на в'язких вологих грунтах.

Висновки. 1. Застосування гнучких ГТЕ в РО землерийних машин ковшового типу володіє більш широкими резервами щодо усунення ефектів налипання розроблюваного середовища на внутрішні поверхні ковша, сприяє очищенню всього РО, створює нові можливості для проектування нових конструкцій, дозволяе підвищити надійність i довговічність шарнірних з'єднань ковша з елементами його приводу.

2. Застосування ГТЕ перспективно для землерийних машин циклічної і безперервної дії. 


\title{
Література:
}

1. Тесленко І.О. Шляхи вдосконалення робочих органів універсальних землерийних машин // Науково-технічний збірник «Вісник Національного транспортного університету» Київ 2016. Випуск 2 (35). C. 211-218.

2. Аулін В.В., Тихий А.А., Карпушин С.О., Деревянко Д.А. Підвищення енергоефективності обробітку грунту зменшенням процесів його налипання на поверхні робочих органів. Центральноукраїнський науковий вісник. Технічні науки. Кропивницький 2019. Випуск 2 (33). C. 3-16. DOI: https://doi.org/10.32515/2664-262X.2019.2(33).3-16

3. Голубченко O.I., Хожило М.Е., Огляд та пропозиції конструкцій активного робочого обладнання землерийно-транспортних машин безперервної дії // Вісник Придніпровської державної академії будівництва та архітектури. Дніпро 2011. Випуск 6-7. С. 48-55.

4. Пат. 4920 Україна, Ківш скрепера МПК Е02F 3/64. Заявл. 24.05.2004; Опубл. 15.02.2005. бюл. №2 Авт. Хмара Л.А., Карпушин С.О., Старунський С.В.

5. Пат. 35362 Україна, Робоче обладнання одноківшового екскаватора МПК Е02F 3/28. Заявл. 29.04.2008; Опубл. 10.09.2008. бюл. № 7 Авт. Карпушин С.О.

DOI https://doi.org/10.30525/978-9934-26-046-9-24

\section{REGULAR THERMAL REGIME OF A SYSTEM OF BODIES}

\author{
Peretiaka N. O. \\ Ph. D. of Engineering Sciences, Associate Professor \\ Odesa State University of Intelligent Technologies and Communications \\ Odesa, Ukraine
}

Rolling bearings are widely used in machines. Good bearing performance depends on the correct calculation of the maximum load. There is a lot of research in the field of vibration and acoustic diagnostics. But the thermal control method remains very effective in detecting faults [1].

Works $[2,3,4]$ are devoted to the study of heat transfer in rolling bearings. However, studies on the regular thermal conditions of rolling bearings are not enough.

Consider a rolling bearing as a composite body, consisting of several parts, the materials of which differ significantly in thermal properties. For 100 